logos_i_ethos_2020_1_(53), s. 31-53

DOI: http://dx.doi.org/10.15633/lie.3688

Bożena Listkowska

https://orcid.org/0000-0002-6635-5934

Uniwersytet Kazimierza Wielkiego

\title{
Rola wartości w dążeniu do zrozumienia miłości. Wokół filozofii Mieczysława Gogacza
}

\section{Wprowadzenie}

Zrozumienie miłości wydaje się kluczowe dla zrozumienia człowieka. Wielu myślicieli uznaje zdolność do miłości - obok rozumności i wolności - za konstytutywną własność człowieka jako człowieka. Próby zrozumienia miłości są próbami zrozumienia istoty człowieczeństwa. Uznanie zdolności do miłości za istotną własność bytu ludzkiego charakteryzuje także filozofię Mieczysława Gogacza, twórcy tomizmu konsekwentnego. Dąży on do uprawiania filozofii - w tym filozofii człowieka - w sposób maksymal-

Bożena Listkowska - ukończyła magisterskie i doktoranckie studia filozoficzne na UKSW w Warszawie. Od 2012 roku adiunkt w Instytucie Filozofii UKW w Bydgoszczy. Zainteresowania badawcze: współczesna filozofia polska (neotomizm, fenomenologia, filozofia dialogu), w szczególności, antropologia filozoficzna i etyka. Jest autorką m.in. prac: Walka o realistyczną wizję Boga, człowieka $i$ świata w myśli Martina Bubera, „Przegląd Filozoficzny” 24 (2015) 4, s. 149170; Podmiot czy przedmiot? Józefa Tischnera i Mieczysława Krąpca spór o koncepcję człowieka, „Filo-Sofija” 15 (2015/4/1) 31, s. 229246 oraz współredaktorką serii: Tomizm polski 1879-1918. Stownik filozofów, Radzymin 2014; Tomizm polski 1919-1945. Stownik filozofów, Radzymin 2015 i Tomizm polski 19461965. Słownik filozofów, Radzymin 2015.

nie realistyczny. Swoją uwagę skupia na odkrywaniu, kim jest człowiek jako byt, stroniąc od rozważania jego doświadczenia bycia człowiekiem. Podkreśla, że chce zajmować się realnym człowiekiem, a nie ideami człowieka. Sądzi, że filozofia realistyczna, ujmując człowieka zgodnie z tym, kim jest, służy jego dobru, podczas gdy filozofie idealistyczne, 
czerpiąc w większej mierze $\mathrm{z}$ wyobraźni twórcy niż rzeczywistości, nie zawsze mu służą. Filozofia człowieka winna opowiadać się po stronie rzeczywistości, ponieważ odwołują się do niej etyka, pedagogika, prawo i medycyna.

Refleksję nad miłością Gogacz podejmuje na dwóch płaszczyznach: psychologiczno-teologicznej i metafizycznej. Ponieważ w metafizyce miłości nie ma miejsca na wnikanie w głąb ludzkiego doświadczenia, autor przenosi analizy tego doświadczenia na płaszczyznę psychologiczno-teologiczną. Metafizyka miłości, wskazując przyczyny tego, że miłość jest i czym jest, nie daje pełnego wyjaśnienia miłości. Szeregowanie bytów i ich elementów w łańcuchy przyczyn i skutków ukazuje strukturę rzeczywistości, nie jej dynamikę i rozwój. Człowiek nie tylko jest określoną strukturą ontyczną, lecz żywą całością. Aby go zrozumieć, nie wystarczy zidentyfikować jego pryncypia. Trzeba podążyć ścieżkami jego myśli i uczuć. W poznawaniu rzeczywistości ważna jest wierność rzeczywistości, ale aby ją zrozumieć, trzeba się trochę od niej oddalić. Tak jak $\mathrm{w}$ galerii, gdzie oglądając obrazy, podziwia się je nie tylko z bliska, ale także z pewnego dystansu. Dalsza perspektywa nie niszczy bliższej, lecz ją uzupełnia. Tomizm konsekwentny jest spojrzeniem na miłość z bliższej perspektywy. Pozwala dostrzec byty i ich elementy, ale pomija horyzont. Analiza ludzkiego doświadczenia jest perspektywą dalszą, skoncentrowaną na horyzoncie ${ }^{1}$.

Celem artykułu jest pokazanie, że dążenie do wyjaśnienia, czym jest miłość, wymaga uzupełnienia przedmiotowego ujęcia człowieka ujęciem podmiotowym. Filozofia miłości winna ukazywać człowieka nie tylko jako byt zdolny do budowania relacji miłości, lecz także jako byt w specyficzny sposób miłość przeżywający. Zrozumienie, dlaczego miłość się rodzi, dlaczego kieruje się ku tej, a nie innej osobie i dlaczego niekiedy zamiera, wymaga analizy ludzkiej świadomości. Poszerzenie metafizyki miłości o fenomenologię miłości prowadzi do tematu wartości, które

1 Uznanie metafizyki za perspektywę bliższą jest punktem widzenia charakterystycznym dla tomizmu konsekwentnego. Fenomenologowie za bliższą perspektywę uznaliby opis doświadczenia. Artykuł jest propozycją uzupełnienia stanowiska tomizmu konsekwentnego, stąd taka kolejność. 
są horyzontem międzyludzkich relacji. Odwołanie się do nich pozwala pogłębić rozumienie miłości i uniknąć przenoszenia rozważań dotyczących sposobu jej przeżywania z płaszczyzny filozoficznej na psychologiczno-teologiczną. Aby cel ten osiągnąć, najpierw zostaną ukazane niedokładności terminologiczne koncepcji miłości Gogacza w obecnym jej kształcie i błędne interpretacje, do których mogą one prowadzić. Następnie zostanie przedstawione psychologiczno-teologiczne ujęcie miłości wraz z rodzącymi się na jego gruncie problemami, później ujęcie metafizyczne i jego ograniczenia, a na końcu perspektywy rozważań, jakie przed filozofią miłości otwiera aksjologia. Refleksja nad perspektywami zostanie poprzedzona ukazaniem rozumienia aksjologii, do jakiego odwołuje się Gogacz na różnych etapach swojej twórczości. Wbrew temu, co sądzi filozof, aksjologia nie jest przeszkodą w poszukiwaniu prawdy o człowieku, lecz pomocą w zrozumieniu podmiotowego aspektu jego bytowania, na co zwracali uwagę inni współcześni filozofowie polscy podejmujący problematykę miłości, m.in. Antoni Siemianowski i Karol Wojtyła.

\section{Psychologiczno-teologiczne ujęcie miłości}

Najwięcej uwagi problematyce ludzkiej miłości Gogacz poświęca w pracach Jak traci się miłość (1982), Ciemna noc miłości (1985) i Błędy brata Ryszarda (1975). W sposobie patrzenia na miłość dominuje tu perspektywa psychologiczno-teologiczna. Przyjmując ją, twórca tomizmu konsekwentnego stwierdza: „[...] miłość jest to [...] wierna i trwała obecność przy nas, wybranej przez nas, jedynej osoby bez której cierpimy, bez której świat nie ma sensu, bez której my sami się gubimy"2. W innym miejscu zaś, pisze: „[Miłość] Jest dniem dzisiejszym, w którym brak kogoś ukochanego wydaje się wiecznością. [...] jest zachwytem, który w bolesnej tęsknocie domaga się nieustannej obecności, nieustannego zasilania serca. Bez tego zachwytu ludzkie serce zamiera lub rani

2 M. Gogacz, Jak traci się miłość (esej ascetyczny), Warszawa 1982, s. 132, http://www.katedra. uksw.edu.pl/gogacz/ksiazki/jak_traci_sie_milosc.pdf (25.11.2019). 
je cierpienie. [...] miłość wymaga obecności”3. Miłość jest środowiskiem życia człowieka, jego domem. Utrata miłości przynosi tak dojmujący ból, że może prowadzić do rozpaczy, a nawet do śmierci. Psychika ludzka przystosowuje się do odbioru dobra, którym jest ukochana osoba. Utrata jej rodzi poczucie pustki, której nie może wypełnić żadna inna osoba. Obdarzenie miłością kogoś innego i przyjęcie jego miłości oznacza konieczność przebudowy całej psychiki kochającego.

Życie ludzkie jest procesem utraty miłości. Jest traceniem miłości nieumiejętnej i uczeniem się miłości, która służy człowiekowi, chroni jego dobro, pozwala mu wzrastać. Książka Jak traci się miłość pokazuje, że człowiek w budowanych przez siebie relacjach popełnia błędy, a w konsekwencji doświadcza cierpienia. Autor prezentuje obrazy, w których bohaterowie nie potrafią kochać albo kochają w taki sposób, który nie pozwala miłości się rozwijać, niszczy wzajemne zaufanie, a niekiedy samą miłość. Błędy przedstawione w Jak traci się miłość można sprowadzić do trzech głównych: sytuacji, kiedy człowiek za bardzo kocha, sytuacji, kiedy człowiek za mało kocha i sytuacji, kiedy człowiek nie obdarza miłością drugiego człowieka. Błędy te polegają na niewłaściwej mierze miłości. Gdy człowiek kocha za bardzo, stawia kochaną osobę na pozycji Boga. Staje się ona dla niego całym światem, zwornikiem jego uczuć. Taka miłość musi się załamać, ponieważ żaden człowiek nie jest w stanie udźwignąć zbyt wielkiej miłości. Kończy się ona niepodjęciem jej przez kochaną osobę, wycofaniem się w obliczu oczekiwań, którym nie sposób sprostać. Drugi błąd to sytuacja, kiedy człowiek kocha za mało, czyli kocha tylko określone cechy osoby. W istocie kocha on swoje marzenia, nie żywą osobę. Miłość kończy się, gdy okazuje się, że wybrana osoba różni się od wyobrażeń, że nie jest tak idealna, jak wyglądała w marzeniach. Trzecim błędem jest sytuacja, gdy człowiek nie podejmuje niczyjej miłości i nikogo miłością nie obdarowuje. Wybiera wolność i niezależność, czyli samego siebie. Niepodjęcie niczyjej miłości i nieobdarzenie nikogo miłością prowadzi do stagnacji, martwoty,

3 M. Gogacz, Błędy brata Ryszarda, Warszawa 1975, s. 104, http://www.katedra.uksw.edu.pl/ gogacz/ksiazki/bledy_brata_ryszarda.pdf (25.11.2019). 
psychicznego samounicestwienia. Wybór siebie jest niezgodny z ludzką naturą, w której tkwi nastawienie na drugą osobę, życie w środowisku miłości.

W Ciemnej nocy miłości autor koncentruje się nie tyle na błędach popełnianych $w$ relacjach, ile na cierpieniu wywołanym brakiem miłości. Ukazuje los nieodwzajemnionej i niewyznanej miłości, która w jednej z osób przyjmuje postać amor, podczas gdy w drugiej pozostaje na poziomie przyjaźni. Osoba przeżywająca miłość stopniowo uświadamia sobie swoją sytuację i próbuje się z nią pogodzić. Wie, że warunkiem miłości jest wolność, że miłość jest darem i nie można jej sobie wywalczyć. Czeka więc, licząc, że ukochana osoba obdarzy ją miłością. Jedynym błędem kochającego jest $w$ tym przypadku niezrozumienie drugiej osoby, uznanie znaków przyjaźni za znaki miłości, zwlekanie z wyznaniem nastawień. Zarówno Jak traci się miłość, jak i Ciemna noc miłości pokazują, że sposobem na przetrwanie cierpienia związanego z miłością jest zwrócenie się do Boga, uczenie się trwania w miłości do nieobecnego człowieka w oparciu o miłość do nieobecnego w zmysłach Boga: „Bóg realnie obecny w osobie ludzkiej [...] nie daje się doznawać naszej psychice [...]. A jednak kierujemy do Niego swą miłość, wierzymy [...], że obdaruje nas [...] obecnością. Podtrzymuje nas nadzieja. I może sposób przeżywania w tym życiu miłości do Boga [...] stanie się dla nas perspektywą i drogą do przetrwania zdarzającej się rozłąki lub odejścia tych, których [...] ukochaliśmy"4.

Perspektywa psychologiczno-teologiczna tylko częściowo przybliża problemy miłości. Cechą analiz przeprowadzonych w Jak traci się miłość i w Ciemnej nocy miłości jest skoncentrowanie na wewnętrznych przyczynach kryzysów miłości. Filozof ukazuje niedojrzałość bohaterów, ich błędne przekonania na temat miłości, niecierpliwość, zazdrość, egoizm, przywiązanie do własnych planów, przedkładanie wyobrażeń o idealnym przedmiocie miłości nad realne osoby, lęk przed utratą wolności. Perspektywa psychologiczno-teologiczna nie daje całościowego obrazu

4 M. Gogacz, Człowiek i jego relacje (materiały do filozofii człowieka), Warszawa 1985, s. 6-7, http://www.katedra.uksw.edu.pl/gogacz/ksiazki/czlowiek_i_jego_relacje.pdf (25.11.2019). 
miłości. Ukazuje tylko przeżycia kochającego. Nie wyjaśnia dostatecznie szczegółowo, dlaczego miłość się kończy lub dlaczego w ogóle się nie zaczyna. Nie wskazuje na przyczyny pozapsychiczne problemów. Pokazuje sposób przeżywania miłości, zmagania wewnętrzne, pytania stawiane Bogu i samemu sobie. Sugeruje, jak radzić sobie z cierpieniem spowodowanym trudnościami w miłości, ale nie tłumaczy, co jest warunkiem narodzin miłości oraz jej trwania. Nie wyjaśnia też, dlaczego miłość nie zostaje odwzajemniona.

\section{Miłość z perspektywy metafizyki człowieka}

W pracach z zakresu metafizyki człowieka Gogacz nie podejmuje kwestii problemów miłości. Określa, czym jest miłość. Twierdzi, że jest ona relacją osobową, która wspiera się na transcendentalnej własności realności. Własność ta przysługuje każdemu bytowi z racji obecnego w nim aktu istnienia. Miłość jest bytem niesamodzielnym, zapodmiotowanym w dwóch samodzielnych bytach osobowych. Jest relacją, tj. przypadłością. Nie może istnieć bez podmiotu i kresu. Miłość jest najbardziej podstawowym odniesieniem dwóch osób. Wyprzedza poznanie oraz decyzje. Przyczyną miłości międzyludzkiej jest akt istnienia obecny w strukturze ontycznej osoby, napotkany przez intelekt możnościowy drugiej osoby i rozpoznany jako należący do bytu o tej samej naturze. To rozpoznanie skutkuje zrodzeniem „słowa serca”, skłaniającego wolę do zwrócenia się ku bytowi i nawiązania z nim osobowej relacji ${ }^{5}$.

Ukazane ujęcie miłości wymaga doprecyzowań. Gogacz wyróżnia następujące odmiany miłości: connaturalitas (miłość naturalna, czyli życzliwość), concupiscentia (miłość uczuciowa, czyli zakochanie), dilectio (miłość osobowa, czyli angażująca całą osobę, tj. intelekt, wolę oraz uczucia). Do odmiany miłości dilectio należą: amicitia (przyjaźń), amor (miłość powiązana z cierpieniem), caritas (miłość troskliwa, nieoczekująca wzajemności), agape (miłość Boga do człowieka). Twórca tomizmu konsekwentnego stosuje polski termin „miłośc”” do wszystkich wymienionych 
odmian miłości. Szczególnie kontrowersyjne jest stosowanie terminu „miłość" w odniesieniu do życzliwości. Zmusza to bowiem do stwierdzenia, że wszyscy ludzie odnoszą się do siebie z miłością ${ }^{6}$. Można zgodzić się, że ludzie z natury odnoszą się do siebie z życzliwością, trudno jednak uznać, że z natury odnoszą się do siebie z miłością. Stosowanie terminu „miłość” w znaczeniu „życzliwość" prowadzi do utopijnego obrazu rzeczywistości. Potrzebę odróżnienia życzliwości od miłości potwierdza doświadczenie potoczne i intuicja językowa, które rozróżniają nawet zakochanie od miłości, a cóż dopiero życzliwość i miłość 7 .

Opisując relację miłości, Gogacz stwierdza, że jest ona wzajemnym przystosowaniem. W pracy Człowiek i jego relacje pisze: „Miłość jest wytworzonym w dwu osobach przez wzajemne ich oddziaływanie na siebie tym przystosowaniem, które powstaje w wyniku faktu, że istnieją. Z tego względu miłość ze swej natury jest bezinteresowna, jest wzajemną radością, wywołaną tym, że jest przy mnie ta osoba, której wierzę, której ufam, a raczej tej osobie, która jest obecna, która istnieje i jest przy mnie, wierzę i ufam"8. W przytoczonym fragmencie autor akcentuje istnienie jako powód wzajemnego przystosowania. Wyeksponowanie istnieniowego aspektu relacji może prowadzić do interpretacji, że dowolne dwie osoby są $\mathrm{w}$ stanie zbudować relację miłości wyłącznie $\mathrm{z}$ racji wyposażenia ontycznego i obecności. Akt istnienia jest wystarczającą podstawą ku temu, by miłość mogła zaistnieć. Ale czy faktycznie autor chce to powiedzieć? Jego analizy są dwuznaczne. $Z$ jednej strony twierdzi, że przyczyną miłości jest istnienie, $\mathrm{z}$ drugiej zaś zauważa, że relacja miłości zależy od tworzących ją osób i że ludzie, z którymi łączą danego człowieka relacje, wnoszą pewne treści w jego obszar bytowy. Nie zmieniają go istotowo, ale mogą go zmieniać przypadłościowo. Analizy te autor

6 „Oddziałując na siebie swym istnieniem, dwie osoby wywołują w sobie relację życzliwości, akceptacji, którą św. Tomasz nazywa miłością. Jest to bowiem spotkanie z motywu wyłącznie istnienia. Jest więc całkowicie bezinteresowne. Jest w pełni miłością" (M. Gogacz, Człowiek i jego relacje, dz. cyt., s. 17).

7 Por. M. Gogacz, Elementarz metafizyki, Suwałki 1996, s. 124, http://www.katedra.uksw.edu. pl/gogacz/ksiazki/elementarz_metafizyki.pdf (25.11.2019).

8 M. Gogacz, Człowiek i jego relacje, dz. cyt., s. 163. 
kończy stwierdzeniem, że w związku z tym nie bez znaczenia jest, z kim łączą człowieka relacje, komu człowiek ufa i z kim wiąże swoje nadzieje. Może więc - według autora - przyczyną miłości jest nie tylko istnienie?

Jak można doprecyzować i zreinterpretować metafizyczne ujęcie miłości twórcy tomizmu konsekwentnego? Po pierwsze, wydaje się, że z racji współodpowiedniości natur każdą osobę można obdarzyć życzliwością, ale nie z każdą można się związać miłością uczuciową, a tym bardziej osobową. Aby zbudować miłość, potrzebne jest coś więcej niż sama obecność. Równie ważny jest istotowy aspekt relacji: przypadłości materialne i niematerialne, relacje realne i myślne łączące wybraną osobę z innymi bytami i wytworami, jej upodobania i wybory, przekonania, usprawnienia intelektu i woli i inne własności, które wraz z podłożem istotowym można by określić mianem natury indywidualnej. Przyczyną życzliwości jest współodpowiedniość natury gatunkowej, a przyczyną relacji miłości współodpowiedniość natur indywidualnych. Bez podobieństwa tych ostatnich trudno zbudować trwałą obecność. Brak wspólnych przekonań, wartości i celów prowadzi raczej do mijania się niż współobecności.

Gogacz nie wspomina o konieczności pewnego podobieństwa natur indywidualnych do zaistnienia miłości. Nie przykłada też szczególnego znaczenia do istotowych relacji. Twierdzi, że wyłącznie relacje istnieniowe (miłość, wiara, nadzieja) przystosowują i upodabniają do siebie osoby, ponieważ tylko one są dwukierunkowe, tzn. podmiot miłości jest zarazem jej kresem, a kres miłości jest zarazem podmiotem. Dwukierunkowość relacji osobowych sprawia, że są one rodzajem wymiany, przepływu tego, co niosą w sobie własności transcendentalne. Relacje istotowe (poznanie, decyzje) są jednokierunkowe, czyli nieobopólne i nie uobecniają osób. Mogą jednak dzięki sprawnościom intelektu i woli wspierać istnieniowe relacje w ich trwaniu. Mogą też, gdy brak osobom usprawnień, niszczyć wspomniane relacje. $Z$ metafizycznego punktu widzenia problemy w relacji miłości biorą się właśnie z braku sprawności, niedoskonałego działania zmysłowych i umysłowych władz człowieka. Trwanie miłości wymaga ich wychowania. Ujęcie metafizyczne, ukazujące pierwsze przyczyny bytu, wydaje się niewystarczające 
do wytłumaczenia miłości. Ujmuje ono to, co najbardziej podstawowe ontycznie. Brakuje mu narzędzi do uchwycenia tego, co bardziej szczegółowe i drugorzędne ontycznie, ale dla zrozumienia miłości istotne?

\section{Myślenie wartościujące}

Analiza psychologiczno-teologiczna ani metafizyczna nie omawiają problematyki miłości w sposób wyczerpujący. Podejście psychologiczno-teologiczne jest zbyt subiektywne, „przeżyciowe”, niedostatecznie filozoficzne. Podejście metafizyczne jest zbyt ogólne i schematyczne. Chcąc rozważyć kwestię miłości bardziej szczegółowo, warto sięgnąć do innych dyscyplin i metod filozoficznych. Jedną z nich mogłaby być aksjologia fenomenologiczna. Pozwoliłaby ona spojrzeć na człowieka jak na byt doświadczający swojego człowieczeństwa, którego ważnym elementem jest miłość. Ukazałaby go jako osobę zabiegającą o relacje z tym, co uważa za cenne. Rzuciłaby światło na relacje, jakimi wiąże się on z osobami oraz materialnymi i niematerialnymi wytworami kultury. Być może pozwoliłaby też dostrzec przyczyny problemów w miłości, których nie można uchwycić, posługując się metodami metafizycznymi. Dokonanie wglądu w ludzką świadomość ułatwiłoby zrozumienie doświadczenia miłości. Stosunek autora Człowieka i jego relacji do aksjologii jest jednak niechętny. Sądzi on, że myślenie wartościujące, którym posługuje się aksjologia, subiektywizuje rzeczywistość. Adekwatnie ujmuje ją stosowane w metafizyce tomizmu konsekwentnego myślenie identyfikujące.

W myśleniu identyfikującym najpierw wskazuje się wewnętrzne, a potem zewnętrzne przyczyny bytu. Przyczyny wewnętrzne są skutkiem przyczyn zewnętrznych i na nie wskazują. Bez rozpoznania przyczyn wewnętrznych - elementów struktury ontycznej bytu - nie można wskazać przyczyn zewnętrznych. Myślenie identyfikujące wychodzi od przyczyn wewnętrznych, myślenie wartościujące wychodzi od przyczyn

9 Por. A. Andrzejuk, Metafizyka obecności. Wstęp do teorii relacji osobowych, Warszawa 2012, s. 440; A. Andrzejuk, Uczucia i sprawności. Związek uczuć i sprawności w „Summa Theologiae” św. Tomasza z Akwinu, Warszawa 2006, s. 174-175. 
zewnętrznych. Myślenie identyfikujące prowadzi do odpowiedzi na pytanie, czym byt jest, myślenie wartościujące do odpowiedzi na pytanie, czym byt jest dla kogoś. Myślenie wartościujące skutkuje subiektywizmem, gdyż dla każdego człowieka dany byt może być czymś innym. Nie jest ono rozpoznawaniem pryncypiów bytu, ale porównywaniem i ocenianiem. Myślenie identyfikujące jest myśleniem substancjami, myślenie wartościujące jest myśleniem relacjami.

Myślenie substancjami to myślenie, w którym uznaje się, że pierwsze są samodzielne byty, a wtórne są ich relacje. Aby mogło zaistnieć działanie, musi istnieć byt będący w możności działania. W myśleniu relacjami uznaje się natomiast, że pierwsze są relacje: odniesienia, działania, decyzje. One stanowią to, czym byt jest. Ilustracją myślenia relacjami jest stanowisko egzystencjalizmu wyrażone w sentencji „Egzystencja poprzedza esencję". W myśl tego stanowiska człowiek w trakcie życia tworzy samego siebie. Istnienie człowieka wyprzedza jego istotę. Istota jest tworzona w trakcie życia poprzez dokonywane przez człowieka wybory. W przekonaniu twórcy tomizmu konsekwentnego myślenie relacjami, stosowane do zidentyfikowania bytu, jest błędem. Stanowi utożsamienie przyczyny ze skutkiem. Działania są skutkami bytów, a nie ich przyczynami. Człowiek nie jest układem relacji, choć w układzie relacji istnieje. Jest samodzielnym bytem realnym, mającym określoną istotę. Tą istotą nie jest to, co znajduje się poza jego obszarem bytowym. Nie jest nią zespół relacji do innych bytów i rzeczy.

Aby zbudować realistyczną filozofię człowieka, należy najpierw zidentyfikować człowieka, a dopiero potem jego relacje. Te ostatnie winny być uznane za drogę do zrozumienia istoty człowieka, a nie za jego istotę. Utożsamianie bytu z zespołami relacji jest charakterystyczne dla idealistycznych metafizyk relacyjnych wywodzących się od Plotyna. Wartościowanie zastępuje w nich lub wyprzedza identyfikowanie bytu. „Myślenie celami i wartościami jest słuszne i potrzebne. Wymaga jednak rozpoznania, czym jest dany byt [...]. Musi być wyprzedzone metafizycznym rozpoznaniem tak zwanej natury danego bytu" ${ }^{10}$. Pomimo 
przyznania, że myślenie wartościujące jest potrzebne, filozof nie stosuje go w swojej filozofii człowieka. Nie poszerza metafizycznych dociekań o człowieku analizą jego odniesień do wartości i bytów innych niż osobowe. Jego stosunek do aksjologii jako dyscypliny o proweniencji neoplatońskiej pozostaje niechętny ${ }^{11}$.

\section{Nastawienie antyaksjologiczne}

Dążeniem Gogacza jest uprawianie filozofii konsekwentnie realistycznej, analizującej rzeczywistość, a nie jej ujęcia. Bytem jest to, co w swojej strukturze ontycznej zawiera akt istnienia. Terminem „byt” filozof określa wyłącznie to, co realne, odmawiając statusu bytowego temu, co idealne. W Człowieku i jego relacjach (1985) odrzuca istnienie wartości jako idei bytujących poza człowiekiem. Twierdzi, że czynienie tak rozumianych wartości celem postępowania oddala od rzeczywistości, kontaktując $\mathrm{z}$ wytworami myślenia zamiast $\mathrm{z}$ realnymi bytami. Uniemożliwia zbudowanie realistycznej etyki i pedagogiki. Uczynienie celem postępowania dobra lub jakiejkolwiek innej wartości skazuje człowieka na frustrację i niespełnienie. Nie jest on bowiem w stanie stać się doskonale dobry. Nie mniejszym błędem jest uznanie wartości za realne byty zapodmiotowane w substancji człowieka, tj. przypadłości. Uznanie za tak rozumianą wartość np. dobra oznacza, że człowiek jest moralnie dobry, a więc nie musi o bycie dobrym zabiegać. Etyka ani pedagogika nie są mu potrzebne.

W Elementarzu metafizyki (1987) ${ }^{12}$ Gogacz określa aksjologię jako teorię wartościowania, która $\mathrm{w}$ wyniku porównywania bytów ze sobą przypisuje im „własności aksjologiczne”. Własnościom tym autor

11 Zob. M. Gogacz, Osoba zadaniem pedagogiki, Warszawa 1997, s. 46, http://www.katedra. uksw.edu.pl/gogacz/ksiazki/osoba_zadaniem_pedagogiki.pdf (25.11.2019).

12 Prezentując rozwój myśli autora, podaję datę pierwszych wydań publikacji. W przypadku Elementarza metafizyki data podawana w tekście głównym artykułu (1987) jest datą pierwszego wydania i różni się od daty przywoływanej w przypisach i bibliografii (1996), która jest datą drugiego wydania. Korzystam z wersji elektronicznej wydania drugiego, która pod względem merytorycznym nie różni się od wydania pierwszego. 
przeciwstawia „własności istotowe”, które są ontycznym wyposażeniem bytów i przysługują im niezależnie od dokonywanych porównań. Własności istotowe wskazuje metafizyka. Autor wielokrotnie podkreśla potrzebę odróżniania własności istotowych od aksjologicznych, tj. pryncypiów bytu od opinii i ocen ${ }^{13}$. Na tym etapie twórczości przyznaje aksjologii miejsce wewnątrz etyki, która obok teorii wartościowania zajmuje się teorią zasad postępowania. Twierdzi, że filozofia wartości jest potrzebna etyce do ustalania, które powiązania i z jakimi bytami są dla człowieka dobre. Rozpoznanie dobrych skutków powiązań wymaga od aksjologii porównywania ze sobą różnych skutków, do jakich powiązania prowadzą. Tym, co sprawia dobre skutki, jest trwanie relacji osobowych. Według Gogacza wartością nie jest ani człowiek, z którym łączy osobę relacja, ani sama relacja. Jest nią trwanie relacji osobowych ${ }^{14}$.

Dlaczego relacja osobowa nie jest wartością, a jest nią dopiero jej trwanie? Można by sądzić, że jest tak dlatego, że dopiero trwanie relacji owocuje dobrem. Okazuje się jednak, że autor uznaje trwanie relacji za wartość $\mathrm{z}$ innego powodu. Chce uniknąć pomieszania porządku metafizycznego $\mathrm{z}$ aksjologicznym. Zależy mu, by relacji, która jest bytem, nie nazywać wartością, ponieważ wartości kojarzą się z wytworami umysłu, tj. wynikami czynności wartościowania. Pisze: „[...] sam byt jest bytem, nie jest wartością. Jego własność dobra jest dobrem, nie jest wartością. Relacja z tym dobrem jest relacją, a nie wartością" ${ }^{15}$. Ponieważ trwanie relacji osobowych chroni człowieka dobrem, można je uznać za cenne i określić mianem wartości. Chronienie dobrem jest właściwością wyłącznie relacji realnych. Relacje z ideami są relacjami myślnymi, których trwanie nie chroni człowieka i dlatego nie można określić ich mianem wartości.

Trudno zgodzić się z Gogaczem, że tylko trwanie relacji osobowych chroni człowieka dobrem. Wytwory ludzkiego myślenia również mogą mieć tę właściwość. Chroni osoby myśl zawarta w dziełach literatury

13 Z rozumieniem przez Gogacza wartości jako ocen polemizuje Józef Tischner. Por. Wartość i wartościowanie, w: J. Tischner, Myślenie według wartości, Kraków 1982, s. 270-271.

14 Zob. M. Gogacz, Elementarz metafizyki, dz. cyt., s. 57-62.

15 M. Gogacz, Elementarz metafizyki, dz. cyt., s. 62. 
pięknej, filozofii, sztuce. Wychowanie i kształcenie jest w znacznej mierze oparte na przekonaniu o pozytywnym wpływie myśli ludzkiej na wychowanków. Dzięki temu wpływowi mogą oni rozwijać swoje rozumienia i doskonalić postępowanie. Zmiana myślenia pociągająca za sobą zmianę postępowania jest metanoją, która - jak Gogacz często podkreśla - stanowi ważny cel kształcenia i wychowania. I chociaż metanoja jest przede wszystkim zasługą wychowawcy, mają w niej udział także dzieła człowieka. Nawet więc gdyby przyjąć, że wartości są wytworami myślenia, to skutki relacji z nimi są nie tylko myślne, ale także realne. Gogacz jednak widzi w wartościach przede wszystkim fikcję, która nieopacznie włączona do zdań o rzeczywistości, może prowadzić do błędów i skutkować zagrożeniami.

Antyaksjologiczne nastawienie autora spowodowane jest postawą, którą można by nazwać maksymalizmem realistycznym. Od początku twórczości filozoficznej jego stosunek do aksjologii jest niechętny, a z czasem bardziej się pogłębia. W pracy Człowiek $i$ jego relacje (1985) dokonuje on klasyfikacji wartości, wyróżniając wśród nich: osobowe, społeczne, kulturowe i ludzkie. W innym miejscu tej samej pracy dzieli je na podstawowe i wtórne, podkreślając wagę podstawowych, które powstają $\mathrm{w}$ międzyludzkich relacjach. Za podstawowe wartości uznaje wartości osobowe, do których należą: miłość, wiara i zaufanie. W Elementarzu metafizyki (1987) określa aksjologię jako teorię wartościowania, mieszczącą się w obrębie etyki, a wartość jako taki wynik czynności wartościowania ${ }^{16}$, który jest „rozpoznaniem bytu jako dobra dla nas”. Najsurowiej o aksjologii wypowiada się w pracy Osoba zadaniem pedagogiki (1997), w której stwierdza, że jest ona nie tyle filozofią, ile „twórczością artystyczną"17 a wartości są jedynie kompozycjami wyobrażeń

$16 \mathrm{Z}$ takim rozumieniem wartości nie zgodziłby się Józef M. Bocheński. Twierdzi on: „Z wartością związanych jest kilka zabobonów. Jeden z nich miesza wartości z wartościowaniem. Jest to zupełne nieporozumienie, które popełniłby człowiek twierdzący, że liczba jest tym samym, co liczenie. Ten zabobon jest wynikiem psychologizmu [...]", tj. uznania przedmiotów nierealnych za wytwory ludzkiego umysłu (J. M. Bocheński, Sto zabobonów. Krótki filozoficzny słownik zabobonów, Komorów, b.r.w., s. 132).

17 M. Gogacz, Osoba zadaniem pedagogiki, dz. cyt., s. 46. 
i pojęć. Brakuje im istnienia, tj. realności, stąd „[...] nie występują w realistycznej filozofii bytu. Nie są [...] żadnym z elementów strukturalnych bytu ani nie są realnymi bytami. Są wobec tego tylko nazwą fragmentu teorii poznania. Ta nazwa znaczy, lecz niczego nie oznacza. [...]. W filozofii realistycznej wartość może oznaczać jedynie naszą ocenę bytu, jego cechy lub relacji"18. Dla wartości rozumianych inaczej niż wynik czynności wartościowania nie ma miejsca w perfekcjonistycznie realistycznej filozofii autora.

\section{Dobro czy wartość?}

Gogacz we wczesnych swoich pracach często z terminu „wartość” korzysta. Posługuje się nim, pisząc m.in. o światopoglądzie, kulturze, życiu duchowym itp. We wszystkich wymienionych przypadkach traktuje jednak wartości jako wytwory ludzkiego umysłu, nie zaś jako realne byty. $\mathrm{Z}$ tego powodu - przynajmniej w jakiejś mierze - umniejsza ich rolę w życiu człowieka. Tymczasem, nawet jeśli wartości są tylko wytworami myślenia, a każdy człowiek jest bytem myślącym, to każdy funkcjonuje w świecie wartości. Wewnętrzny świat człowieka jest światem wartości. Nie są one jednakowo ważne, ale są uporządkowane w sposób hierarchiczny. O tym, jakie miejsce w hierarchii zajmują określone wartości, decyduje intelekt, wola oraz uczucia. Interesującą koncepcję hierarchii wartości formułuje Antoni Kępiński w pracy Psychopatie. Pomimo tego, że operuje biologiczno-psychologicznym rozumieniem wartości (wartość to bodziec odczytany przez układ nerwowy jako ważny, tj. domagający się odpowiedzi), zwraca uwagę na filozoficznie istotny aspekt bytu ludzkiego - wpływ tego, co wartościowe na postępowanie. Hierarchia wartości nie jest niezmienna w ciągu całego życia, lecz może podlegać i faktycznie podlega zmianom. Każdy człowiek dysponuje nie jedną, lecz dwiema hierarchiami wartości, a wspomniana zmienność dotyczy obydwu. Pierwsza z nich to hierarchia idealna, ukonstytuowana przez wartości cenione i świadomie wybrane. $\mathrm{Na}$ jej podstawie człowiek tworzy 
obraz samego siebie. Obraz ten wyraża, kim człowiek chciałby być i jak widzi samego siebie. Druga hierarchia wartości jest hierarchią realną, zespołem wartości, które człowiek faktycznie realizuje. Hierarchii tej nie jest on w pełni świadomy. Powstaje ona poprzez wielokrotne powtarzanie danego postępowania, które w procesie „torowania” przekształca się w nawyki i przyzwyczajenia.

Koncepcja Kępińskiego tłumaczy dwie kwestie: rozbieżność pomiędzy myśleniem i postępowaniem oraz rozbieżność pomiędzy obrazem samego siebie a obrazem człowieka wytworzonym przez jego otoczenie. Rozbieżność między myśleniem i postępowaniem bierze się stąd, że ludzka świadomość najbardziej angażuje się w wykonywanie działań nowych, które dlatego, że są nowe, traktowane są jako trudne, wymagające skupienia. Kiedy stają się nawykami, przestają angażować uwagę. Działania nawykowe ukazują, jak człowiek zazwyczaj działa, czyli jaka jest jego realna hierarchia wartości. On sam w nieznacznej mierze zdaje sobie $\mathrm{z}$ niej sprawę, ponieważ $\mathrm{w}$ centrum jego uwagi znajdują się wartości idealne, których realizacji się jeszcze nie podjął. Ponieważ na nich jest skoncentrowany, sądzi, że te wartości najlepiej go opisują. Obraz siebie tworzy na ich podstawie. Otoczenie natomiast tworzy sobie obraz człowieka na podstawie jego działania. Hierarchie idealna i realna nie są od siebie odizolowane. Każdorazowe działanie jest konfrontacją obu hierarchii. Im działanie jest bardziej świadome, tym większego wysiłku wymaga próba uzgodnienia hierarchii wartości. Dzięki zderzaniu się tych hierarchii i pracy nad sobą człowiek może się w ciągu życia zmieniać ${ }^{19}$.

Przytoczony sposób rozumienia ludzkiego działania koresponduje z filozofią Arystotelesa, a pośrednio św. Tomasza z Akwinu. Transponując koncepcję Kępińskiego na grunt filozofii klasycznej, można przyjąć, że w człowieku są obecne dwa sposoby odnoszenia się do dóbr przyjemnych, użytecznych i szlachetnych: odniesienie pozostające w sferze myśli i odniesienie realizujące się w sferze działania. Człowiek działa zgodnie z uzyskanymi przez intelekt i wolę sprawnościami oraz nawykami 
wytworzonymi przez władze zmysłowe. Do relacji miłości wnosi wypracowane sprawności i nawyki, a także myślne odniesienia do dóbr różnego rodzaju. Miłość jest specyficznym terenem ujawniania się myślnych i realnych odniesień do dóbr. W pierwszej fazie miłości, dzięki rozmowom, ujawniają się przede wszystkim myślne odniesienia do dóbr, gdyż ludzie mają jeszcze niewielki wgląd w postępowanie kochanej osoby. W miarę upływu czasu widoczne stają się także realne odniesienia do dóbr różnego rodzaju. Wtedy też na jaw wychodzą rozbieżności między odniesieniami myślnymi i realnymi. Bywa, że rozbieżności te są tak duże, iż prowadzą do rozpadu relacji ${ }^{20}$.

Według Arystotelesa tylko ludzie szlachetni są w stanie zbudować trwałą relację. Tylko kierowanie się dobrem szlachetnym pozwala na zbudowanie bezinteresownej przyjaźni. Przyjaźnie oparte na nierówności, tj. skierowaniu jednego człowieka ku dobru szlachetnemu, a drugiego ku przyjemnemu lub korzystnemu (albo obydwu ludzi ku niższym dobrom) nie są prawdziwymi przyjaźniami i wcześniej czy później się rozpadają. Wydaje się, że analogicznie rzecz się ma z miłością. Różnica pomiędzy myślnymi i realnymi odniesieniami do dóbr sprawia, że chociaż czasami wydaje się, iż relacja miłości łączy osoby podobne $\mathrm{z}$ punktu widzenia wybieranych dóbr, faktycznie tak nie jest. Wówczas, posługując się terminologią Gogacza, ale odchodząc nieco od jego rozumienia miłości, trzeba uznać, że wzajemne przystosowanie nie jest możliwe. Może ono dokonać się na poziomie władz zmysłowych, ale nie na poziomie władz duchowych. Może stać się co najwyżej przyzwyczajeniem i wzajemnym znoszeniem, ale nie głębokim zżyciem opartym na bliskości i zrozumieniu. Rozpad niektórych relacji jest więc nieunikniony i nie musi wynikać z popełnionych błędów.

Jak pokazuje myśl Arystotelesa, o człowieku i jego relacjach można mówić bez odwoływania się do kategorii wartości. Wydaje się jednak, że takie ujęcie ogranicza perspektywę rozważań. Odniesienie się do wartości nie jest tylko zmianą języka. Aksjologia pozwala spojrzeć

20 Por. Arystoteles, Etyka nikomachejska, tłum. D. Gromska, Warszawa 2008, s. 239-265. 
na człowieka inaczej niż metafizyka. Dostrzega w nim coś więcej niż strukturę ontyczną. Zagląda w głąb świadomości. Widzi w osobie indywiduum kierujące się tylko sobie właściwymi hierarchiami wartości. Różnorodność wartości znacznie lepiej oddaje niuanse ludzkich wyborów niż trzy rodzaje dóbr. Wartości pokazują, czym żyje jednostka, czego pragnie, do czego dąży, ku czemu się zwraca. Przybliża do odpowiedzi na pytanie, kim jest jako indywiduum i co skłania ją do nawiązywania relacji. Gdyby za Józefem Tischnerem spojrzeć na człowieka jak na osobę funkcjonującą w horyzoncie wartości, można by stwierdzić, że miłość jest możliwa wtedy, gdy osoby łączy wspólny horyzont. I choć wszystkie osoby żyją w tej samej rzeczywistości, to ich horyzonty aksjologiczne są niekiedy bardzo odmienne. Dla rozważań nad miłością istotne jest przyjrzenie się aksjologicznemu horyzontowi osoby. Nie jest on jedną z wielu okoliczności budowania relacji, ale ważnym warunkiem jej zaistnienia i trwania.

\section{Odpowiedź na wartości}

Poszerzenie refleksji filozoficznej o zagadnienie wartości oznacza konieczność zmodyfikowania rozumienia doświadczenia i skorzystania z metod fenomenologicznych. Tutaj pojawia się jednak trudność, ponieważ Gogacz analizę doświadczenia uważa za psychologizm, a korzystanie $\mathrm{z}$ metod fenomenologicznych za właściwe dla teorii poznania, a nie filozofii człowieka. Sądzi, że pozostanie przy kategorii dobra wystarcza do wyjaśnienia ludzkiego postępowania i osobowych relacji. Wydaje się jednak, że włączenie do filozofii zagadnienia wartości nie musi oznaczać porzucania rzeczywistości, a kategorie takie jak dobro i wartość się nie wykluczają. Pokazują to prace Dietricha von Hildebranda, a wśród polskich myślicieli Siemianowskiego, w których kategorie te dopełniają się i współpracują ze sobą. Siemianowski podkreśla rolę wartości w życiu człowieka, ale zaznacza, że pełne poznanie wartości nie jest możliwe przy pomocy pojęć i sądów. Wymaga ono ujmowania ich w sposób intuicyjny, odpowiadania na nie uczuciami, aktami woli, postawą i zachowaniem. Doświadczenie wartości dokonuje się poprzez zaangażowanie rozumu 
i serca ${ }^{21}:$ „[... kto usiłuje się zbliżyć do wartości wyłącznie na drodze racjonalnego poznania, ten do nich nie dociera" ${ }^{22}$. Rozważanie wartości musi być poprzedzone odczuciem wartości. Chłodny racjonalista nie ma do nich dostępu.

Jak twierdzi Siemianowski, bogactwo wartości jest olbrzymie. Są wartości, które człowiek tworzy, i wartości autonomiczne, niezależne od niego. Podobnie rzecz się ma z hierarchiami wartości. Człowiek może tworzyć własne, chociaż istnieje także hierarchia obiektywna. Wartości są zawsze wartościami czegoś, są niesamodzielne bytowo w stosunku do nosicieli. Nie są ideami bytującymi w odrębnym świecie ani też przypadłościami substancji. Stanowią obiektywne kwalifikacje bytu, nadbudowujące się nad strukturą nosiciela na podłożu jego natury (wartości ontyczne) oraz własności (wartości kwalitatywne). Rangi wartości nie umniejsza to, że ich status ontyczny wymyka się pojęciom. Oznacza tylko, że próby wyjaśniania wartości w operującym wielorakimi założeniami systemie filozoficznym mogą prowadzić do niepowodzeń. Wartości wymagają własnej ontologii czy też wielu odrębnych ontologii, w zależności od dziedziny, do której należą. Błędem jest jednak rezygnowanie z prób ich poznania: „Jeżeli istota jakiegoś stanu rzeczy narzuca się nam jako niepowątpiewalna, nie wolno nam tego nie uznać jedynie dlatego, że nie potrafimy rozwiązać problemów, jakie przyjęcie tego stanu rzeczy spowoduje"23.

Zaletami aksjologii jest nie tylko ujmowanie rzeczywistości niedostępnej poznaniu zmysłowemu, ale także nośność kategorii wartości dla filozofii człowieka, w tym filozofii miłości. Tak jak psychologiczne ujęcie wartości poszerza perspektywę filozofii człowieka, tak ujęcie fenomenologiczne otwiera zupełnie nowy wymiar dociekań. Widać to w rozważaniach Hildebranda, Siemianowskiego i Wojtyły poświęconych

21 Serce jest tu rozumiane jako duchowe centrum przeżyć. Por. A. Siemianowski, Zrozumieć miłość. Fenomenologia i metafizyka miłości, Bydgoszcz 1998, s. 45, 60, 285. Siemianowski rozumie serce w duchu filozofii Dietricha von Hildebranda. Por. D. Hildebrand, Serce. Rozważania o uczuciowości ludzkiej i uczuciowości Boga-Człowieka, tłum. J. Koźbial, Poznań 1995.

22 A. Siemianowski, Człowiek a świat wartości, Gniezno 1993, s. 119.

23 A. Siemianowski, Człowiek a świat wartości, dz. cyt., s. 19. 
problematyce miłości. Siemianowski zauważa, że człowiek w szczególny sposób uczestniczy w wartościach, kiedy jednoczy się z dobrami, w których wartości są ucieleśnione. Dany przedmiot właśnie dlatego jest dobrem, że ucieleśnia określone wartości. Człowiek dąży do zjednoczenia $\mathrm{z}$ wybranym dobrem, ponieważ zapodmiotowane $\mathrm{w}$ nim wartości poruszają jego serce, wyrywają go $\mathrm{z}$ obojętności. Doświadczenie wartości pokazuje, że miłość nie jest koniecznością ani przypadkiem. Jest odpowiedzią na konkretne wartości ${ }^{24}$, afirmacją wartości obecnych w osobie i samej osoby ${ }^{25}$. Siemianowski utrzymuje, że jakość przeżyć zależy od jakości wartości. Można by zatem powiedzieć, że także „jakość" miłości - jej głębia i trwałość - zależy od ucieleśnionych w dobru wartości. Zwracał na to uwagę Wojtyła w Miłości i odpowiedzialności, wskazując, że w miłości ważny jest nie tylko jej profil subiektywny, czyli autentyczność uczuć, lecz także profil obiektywny, czyli faktyczna obecność w osobie tych wartości, których kochający w niej upatruje. Zdarza się bowiem, że pod wpływem reakcji wzruszeniowo-afektywnych człowiek dostrzega w wybranej osobie wartości, których naprawdę w niej nie $\mathrm{ma}^{26}$.

Fenomenologiczne podejście do wartości rzuca nowe światło na rozumienie miłości. Człowiek, transcendując ku drugiemu ze względu

24 „Miłość [...] jest w nas głosem serca, jakim odpowiadamy na wartości” (A. Siemianowski, Zrozumieć miłość, dz. cyt. s, 297). „Każda próba pominięcia charakteru miłości jako odpowiedzi na wartość prowadzi do przedstawienia jej jako bezwolnej i całkowicie irracjonalnej [...]” (D. Hildebrand, Miłość jako odpowiedź na wartość, tłum. W. Paluchowski, „Logos i Ethos” 37 (2014) 2, s. 234).

25 „Nie wystarczy zaakcentować, że miłość jest odpowiedzią na wartość [...]. Należy też podkreślić, że chodzi w niej o emanację wartości, które są tak związane z osobą, że osoba jako taka, tzn. ta oto indywidualna, niepowtarzalna osoba jawi mi się wartościowa, bezcenna, godna miłości i jest ona pełnym tematem [przeżycia]" (D. Hildebrand, Miłość w odróżnieniu od innych odpowiedzi na wartości, tłum. M. Grabowska, w: O miłości. Antologia, red. M. Grabowski, Toruń 2013, s. 106).

${ }^{26}$ Por. A. Siemianowski, Człowieka a świat wartości, dz. cyt., s. 98-100; A. Siemianowski, Zrozumieć miłość, dz. cyt., s. 78; K. Wojtyła, Miłość i odpowiedzialność, Lublin 2015, s. 73. Zagadnienie różnorodnych zakrzywień obrazu kochanej osoby podejmuje Józef Lipiec w artykule Aksjologia miłości, w: Filozofia - etyka - ekologia. Profesorowi Włodzimierzowi Tyburskiemu w darze, red. P. Domeracki, A. Grzeliński, R. Wiśniewski, Toruń 2015, passim. 
na ucieleśnione w nim wartości i otwierając się na jego obecność, doświadcza nowej rzeczywistości. Dzięki różnym sposobom „bycia dla” dochodzi do pełni swej egzystencji, odnajduje siebie i staje się w pełni sobą. Miłość jako odpowiedź na wartości jest aktem twórczym i osobotwórczym. W Miłości i odpowiedzialności Wojtyła pokazuje, że charakter odpowiedzi na wartości ma zarówno pierwsza faza miłości, będąca reakcją uczuciową na wartości ciała, jak i druga faza, będąca reakcją na wartości duchowe. Wydaje się, że istotne są tu nie tylko wartości ucieleśnione w osobie, lecz także wartości, którymi żyje osoba. Te ostatnie stanowią o wewnętrznym podobieństwie osób, podobnej wrażliwości i możliwości zbudowania wspólnoty aksjologicznej. Okazuje się więc, że wykroczenie poza rzeczywistość dostępną poznaniu zmysłowo-intelektualnemu i zwrócenie się ku sferze intuicji, uczuć i emocji pozwala lepiej zrozumieć człowieka i jego relacje niż trzymanie się rzeczywistości dostępnej wyłącznie intelektowi i zmysłom. Pozwala ująć odcienie rzeczywistości, których kategorie metafizyczne nie są w stanie uchwycić. Jednym $\mathrm{z}$ takich ocieni jest bogactwo wewnętrznego świata człowieka, jego dążenie ku temu, co go porusza, zachwyca i doskonali. Pomimo trudności, jakich z metafizycznego, epistemologicznego i metodologicznego punktu widzenia nastręczają wartości, nie warto wypędzać ich z filozofii. Ceną za to wypędzenie jest spłycenie rozumień, sprowadzenie rozważań o człowieku do analizy kategorii metafizycznych, zbyt pobieżne uchwycenie najważniejszych aspektów ludzkiego bytowania, w tym także miłości ${ }^{27}$.

\section{Zakończenie}

Metafizyka człowieka jest w filozofii człowieka niezbędna. Bez zidentyfikowania pryncypiów człowieka zacierają się granice pomiędzy istotą ludzką a innym istotami żywymi. Różnice te sprowadza się wówczas do tego, co drugorzędne, tj. przypadłości. Konsekwencją takiego sposobu myślenia jest np. etyka Petera Singera, stawiająca moralny znak

27 Por. A. Siemianowski, Zrozumieć miłość, dz. cyt., s. 188. 
równości pomiędzy odebraniem życia zwierzęciu i noworodkowi ${ }^{28}$. Metafizyka człowieka, wskazując istotowe różnice pomiędzy bytami, chroni przed konsekwencjami błędów myślowych. Chociaż jest najważniejszą częścią filozofii człowieka, nie musi jej wyczerpywać. Sięgnięcie do analizy ludzkiego doświadczenia pozwala spojrzeć na osoby ludzkie jak na byty różniące się wrażliwością na wartości. Miłość jawi się wówczas jako fenomen spotkania się dwóch bytów o podobnych hierarchiach wartości budujących relację w oparciu o swoistą wspólnotę wartości. Analiza doświadczenia wartości otwiera przed filozofią perspektywę, której z przyczyn metodologicznych nie może przed nią otworzyć metafizyka człowieka. Pozwala spojrzeć na miłość jak na zjawisko wywołane nie tylko istnieniem, lecz także wartościami drugiej osoby. Z tego punktu widzenia przygotowanie do zbudowania trwałej relacji miłości staje się czymś więcej niż nabywaniem usprawnień intelektu i woli oraz wychowywaniem uczuć. Staje się kształceniem umiejętności patrzenia na drugiego człowieka jak na byt niepowtarzalny, dążeniem do poznania i zrozumienia jego hierarchii wartości, pogłębianiem wrażliwości. Jest stawianiem pytania o wspólny horyzont aksjologiczny. Jest też nieustannym pytaniem siebie o własną hierarchię wartości, kształtowaniem jej w taki sposób, by służyła swojemu twórcy, innym ludziom i wzajemnym relacjom. Uwzględnienie aksjologii wśród dyscyplin filozoficznych tomizmu konsekwentnego wiąże się ze zmianą sposobu rozumienia realizmu. Wymaga przejścia od realizmu idealnego do realizmu realistycznego, mniej skoncentrowanego na precyzji dociekań, a bardziej na zrozumieniu człowieka i jego doświadczeń. Stanowi ujęcie kontrowersyjne, ale być może warte rozważenia.

28 Zob. P. Singer, O życiu i śmierci. Upadek etyki tradycyjnej, tłum. A. Alichniewicz, A. Szczęsna, Warszawa 1997, passim. 


\section{Bibliografia}

Andrzejuk A., Metafizyka obecności. Wstęp do teorii relacji osobowych, Warszawa 2012. Andrzejuk A., Uczucia i sprawności. Związek uczuć i sprawności w „Summa Theologiae” św. Tomasza $z$ Akwinu, Warszawa 2006.

Arystoteles, Etyka nikomachejska, tłum. D. Gromska, Warszawa 2008.

Bocheński J. M., Sto zabobonów. Krótki filozoficzny słownik zabobonów, Komorów, b.r.w. Gogacz M., Błędy brata Ryszarda, Warszawa 1975, http://www.katedra.uksw.edu.pl/gogacz/ksiazki/bledy_brata_ryszarda.pdf (25.11.2019).

Gogacz M., Ciemna noc miłości, Warszawa 1985, http://www.katedra.uksw.edu.pl/gogacz/ ksiazki/ciemna_noc_milosci.pdf (25.11.2019).

Gogacz M., Człowiek i jego relacje (materiały do filozofii człowieka), Warszawa 1985, http:// www.katedra.uksw.edu.pl/gogacz/ksiazki/czlowiek_i_jego_relacje.pdf (25.11.2019).

Gogacz M. Elementarz metafizyki, Suwałki 1996, http://www.katedra.uksw.edu.pl/gogacz/ ksiazki/elementarz_metafizyki.pdf (25.11.2019).

Gogacz M., Jak traci się miłość (esej ascetyczny), Warszawa 1982, http://www.katedra. uksw.edu.pl/gogacz/ksiazki/jak_traci_sie_milosc.pdf (25.11.2019).

Gogacz M., Osoba zadaniem pedagogiki. Wykłady bydgoskie, Warszawa 1997, http://www. katedra.uksw.edu.pl/gogacz/ksiazki/osoba_zadaniem_pedagogiki.pdf (25.11.2019). Hildebrand D., Miłość jako odpowiedź na wartość, tłum. W. Paluchowski, „Logos i Ethos” 37 (2014) 2, s. 219-259.

Hildebrand D., Miłość w odróżnieniu od innych odpowiedzi na wartości, tłum. M. Grabowska, w: O miłości. Antologia, red. M. Grabowski, Torun 2013, s. 132-151.

Hildebrand D., Serce. Rozważania o uczuciowości ludzkiej i uczuciowości Boga-Człowieka, tłum. J. Koźbial, Poznań 1995.

Kępiński A., Psychopatie, Kraków 2013.

Lipiec J., Aksjologia miłości, w: Filozofia - etyka - ekologia. Profesorowi Włodzimierzowi Tyburskiemu w darze, red. P. Domeracki, A. Grzeliński, R. Wiśniewski, Toruń 2015, s. 343-357. Siemianowski A., Człowiek a świat wartości, Gniezno 1993.

Siemianowski A., Zrozumieć miłość. Fenomenologia i metafizyka miłości, Bydgoszcz 1998. Singer P., O życiu i śmierci. Upadek etyki tradycyjnej, tłum. A. Alichniewicz, A. Szczęsna, Warszawa 1997.

Tischner J., Wartość i wartościowanie, w: J. Tischner, Myślenie według wartości, Kraków 1982, s. 270-273.

Wojtyła K., Miłość i odpowiedzialność, Lublin 2015. 


\section{Abstrakt \\ Rola wartości w dążeniu do zrozumienia miłości. Wokół filozofii Mieczysława Gogacza}

Mieczysław Gogacz dąży do uprawiania filozofii maksymalnie realistycznej. Wartości uważa za wytwory umysłu, a nie realne byty. Stąd nie zajmuje się nimi w swojej filozofii. Twierdzi, że budowanie etyki i pedagogiki w oparciu o wartości prowadzi do koncepcji idealistycznych, stawiania wymagań niemożliwych do spełnienia. W artykule argumentuje się, że wartości odgrywają ważną rolę w życiu człowieka. Wewnętrzny świat człowieka jest światem zorientowanym na wartości. Również miłość jest zjawiskiem ściśle związanym z wartościami. Jest ona odpowiedzią na wartości. Hierarchia wartości, którą kierują się osoby, jest wspólnym horyzontem, w którym rodzi się ich miłość.

\section{Słowa kluczowe}

aksjologia, Gogacz Mieczysław, miłość, tomizm konsekwentny, wartość

\section{Abstract \\ The Role of Values in The Pursuit of Understanding Love. Around the Philosophy of Mieczysław Gogacz}

Mieczysław Gogacz pursues a maximally realistic philosophy. He considers values to be products of the mind, not real beings. Hence, he does not work on them in his philosophy. He claims that building pedagogy based on values leads to idealistic conceptions, imposing requirements which are impossible to fulfil. The article argues that values play a major role in human life. The inner world of a human being is a value-oriented world. Love is also a phenomenon closely related to values. It is a response to values. The hierarchy of values that people follow is a common horizon in which their love is born.

\section{Keywords}

axiology, consistent Thomism, Gogacz Mieczysław, love, value 